\title{
Bryophyllum pinnatum and Related Species Used in Anthroposophic Medicine: Constituents, Pharmacological Activities, and Clinical Efficacy*
}

Authors

Affiliations
Karin Fürer ${ }^{1,2}$, Ana Paula Simões-Wüst ${ }^{2}$, Ursula von Mandach ${ }^{2}$, Matthias Hamburger ${ }^{1}$, Olivier Potterat ${ }^{1}$

${ }^{1}$ Division of Pharmaceutical Biology, Department of Pharmaceutical Sciences, University of Basel, Basel, Switzerland

${ }^{2}$ Department of Obstetrics, University Hospital Zurich, Zurich, Switzerland
Key words

- Bryophyllum pinnatum

- Bryophyllum daigremontianum

- Bryophyllum delagoense

- Crassulaceae

- constituents

- anthroposophic medicine

- pharmacological activities

- clinical studies received February 29, 2016 revised March 23, 2016

accepted April 6, 2016

\section{Bibliography}

Dol http://dx.doi.org/

10.1055/s-0042-106727

Published online May 24, 2016

Planta Med 2016; 82: 930-941

(c) Georg Thieme Verlag KG

Stuttgart · New York .

ISSN 0032-0943

\section{Correspondence}

\section{PD Dr. Olivier Potterat}

Division of Pharmaceutical

Biology

Department of Pharmaceutical

Sciences

University of Basel

Klingelbergstraße 50

$\mathrm{CH}-4056$ Basel

Switzerland

Phone: + 41612671534

Fax: + 41612671474

Olivier.Potterat@unibas.ch

\section{Abstract \\ $\nabla$}

Bryophyllum pinnatum (syn. Kalanchoe pinnata) is a succulent perennial plant native to Madagascar that was introduced in anthroposophic medicine in the early 20th century. In recent years, we conducted a large collaborative project to provide reliable data on the chemical composition, pharmacological properties, and clinical efficacy of Bryophyllum. Here, we comprehensively review the phytochemistry, as well as the pharmacological and clinical data. As to the pharmacology, special emphasis is given to properties related to the use in anthroposophic medicine as a treatment for "hyperactivity diseases", such as preterm labor, restlessness, and sleep disorders. Studies suggesting that $B$. pinnatum may become a new treatment option for overactive bladder syndrome are also reviewed. Tolerability is addressed, and toxicological data are discussed in conjunction with the presence of potentially toxic bufadienolides in Bryophyllum species. The few data available on two related species with medicinal uses, Bryo-

\section{Introduction}

$\nabla$

Bryophyllum pinnatum (Crassulaceae) is a perennial succulent herb originating from Madagascar with a long tradition of use in tropical countries. In Europe, its utilization is more recent and almost exclusively restricted to anthroposophic medicine (AM). Introduced in 1921 by Rudolf Steiner initially for the treatment of what at that time was called "hysteria", Bryophyllum is now used for a variety of hyperactivity disorders. Until very recently, only a few experimental and clinical data were available to support the use of

\footnotetext{
* Dedicated to Professor Dr. Dr. h.c. mult. Kurt Hostettmann in recognition of his outstanding contribution to
} natural product research. phyllum daigremontianum and Bryophyllum delagoense, have also been included. Taken together, current data support the use of $B$. pinnatum for the mentioned indications, but further studies are needed to fully understand the modes of action, and to identify the pharmacologically active constituents.

\section{Abbreviations \\ $\nabla$ \\ AM: $\quad$ anthroposophic medicine \\ AUC: $\quad$ area under the curve \\ GABA: $\gamma$-aminobutyric acid \\ i.v.: intravenous \\ i.p.: intraperitoneal \\ NO: $\quad$ nitric oxide \\ OAB: $\quad$ overactive bladder \\ p.o.: peros (oral administration)}

Supporting information available online at http://www.thieme-connect.de/products

B. pinnatum from the perspective of rational phytotherapy. Some years ago we therefore embarked within the Bryophyllum Study Group (see acknowledgments) in a large collaborative project on $B$. pinnatum with the aim to provide reliable clinical, pharmacological, and chemical data on this plant. We review here the current state of knowledge on the phytochemistry, pharmacological properties, and clinical data of $B$. pinnatum. With respect to pharmacology, an emphasis is put on properties related to the use in AM, but other bioactivities are also briefly reviewed.

Some reviews have been previously published on the constituents and pharmacological activities of B. pinnatum [1-3] or, very recently, on the entire genus Kalanchoe, which includes, according to some botanical authors, species of the genus 
Bryophyllum (see below) [4]. While these reviews describe various compounds and bioactivities, none of them addresses the pharmacological and clinical data that support the therapeutic use of Bryophyllum preparations in European countries.

The present review focuses on $B$. pinnatum, but the few data available on Bryophyllum daigremontianum, Bryophyllum delagoense, and the hybrid Bryophyllum daigremontianum x tubiflorum have also been included. The German homeopathic pharmacopeia (HAB) 2014 [5] lists the two species B. pinnatum and $B$. daigremontianum as officinal in its monography "Bryophyllum Rh", and both have been used in AM. B. delagoense was introduced in the 1980s as an anthroposophic medicinal product in Germany, primarily for sedative purposes (Personal communication, Dr. med. Siegward-M. Elsas, see Acknowledgments).

\section{Botany}

$\nabla$

The genus Bryophyllum comprises approximately 25 perennial succulent species that are native to Madagascar [6]. Meanwhile, many of them have been introduced in other tropical areas where they have sometimes become invasive plants. The genus has an intricate taxonomy, with a variable number of species and numerous synonyms, and is regarded by some authors as one of three sections (Kitchingia, Bryophyllum, and Eukalanchoe) of the genus Kalanchoe [6-8]. Bryophyllum species have a unique mode of vegetative reproduction whereby young plantlets develop on the edges of leaves before being shed for propagation. Bryophyllum pinnatum (Lam.) Oken, originally described by Lamarck as Cotyledon pinnata Lam. according to The Plant List [9], possesses approx. 20 synonyms including Bryophyllum calycinum Salisb. and Kalanchoe pinnata (Lam.) Pers., a name that is very frequently used in the literature (For the full list of synonyms, see Table 1 S, Supporting Information). B. pinnatum grows up to $1.5 \mathrm{~m}$ in height and is known by numerous vernacular names, such as life plant, air plant, love plant, miracle leaf, cathedral bells, and Goethe plant. The latter refers to the detailed observations written down by Wolfgang von Goethe (1749-1832) about this plant. Bryophyllum daigremontianum (Raym.-Hamet \& Perrier) A.Berger (syn. Kalanchoe daigremontiana Raym.-Hamet $\& \mathrm{H}$. Perrier) is somewhat smaller (up to $1 \mathrm{~m}$ ) and commonly known as mother of millions, or devil's backbone. Bryophyllum delagoense (Eckl. \& Zeyh.) Druce (syn. Bryophyllum tubiflorum Harv., Bryophyllum verticillatum (Eliott) A. Berger, Kalanchoe delagoensis Eckl. \& Zeyh., Kalanchoe tubiflora (Harv.) Raym.-Hamet, Kalanchoe tuberosa H. Perrier, and Kalanchoe verticillata ScottEliot [9]) grows up to $1.5 \mathrm{~m}$ in height and possesses narrow leaves. Vernacular names include mother of millions, devil's backbone, or chandelier plant. The accepted names of The Plant List, B. pinnatum, B. daigremontianum, and B. delagoense, are consistently used throughout this manuscript, regardless of the names used in the respective original publications.

\section{Constituents}

$\nabla$

Various secondary metabolites have been reported from Bryophyllum species. Particular attention has been paid to the bufadienolides, owing to their toxicological relevance for grazing animals [10], and their various other bioactivities. Beside these, a large number of flavonoids have been reported in B. pinnatum. Further constituents of $B$. pinnatum include triterpenes, various steroids, phenanthrenes, and some ubiquitous compounds. Data on the composition of B. daigremontianum and B. delagoense are almost exclusively limited to bufadienolides.

\section{Bufadienolides}

Thirteen bufadienolides (1-13), including three glycosides, have been reported from B. pinnatum, B. delagoense, B. daigremontianum, and the hybrid $B$. daigremontianum $\mathrm{x}$ tubiflorum ( $\odot$ Table 1, Fig. 1), mostly in conjunction with various bioactivities such as insecticidal and cytotoxic properties [11-23]. A characteristic structural feature is the 1,3,5-orthoacetate function, which is present in about half of these compounds. Bersaldegenin-1-acetate (1), bersaldegenin-1,3,5-orthoacetate (3), the glycoside bryotoxin $A(7)$, and bryotoxin $C$ (= bryophyllin $A, 4$ ) have been found in all species. In contrast, bryophyllins $B(5)$ and $C(6)$ have been reported only in $B$. pinnatum, the glycosides kalantubosides A (11) and B (12) only in B. delagoense, and daigremontianin (9), daigredorigenin-3-acetate (10), and methyl daigremonate (13) only in B. daigremontianum and/or B. daigremontianum $\mathrm{x}$ tubiflorum. The latter compound is listed here on the basis of biogenetic considerations even though it is not a bufadienolide but rather a congener with an opened lactone ring. Bufadienolides were recently quantified in different batches of leaves and press juices of B. pinnatum with the aid of UHPLC-MS/MS. Bryophyllin A (4), bersaldegenin-1-acetate (1), bersaldegenin-3-acetate (2), and bersaldegenin 1,3,5-orthoacetate (3) were found to be the main bufadienolides in the analyzed plants, with the total contents in the leaves ranging from 3.78 to $40.50 \mathrm{mg} / 100 \mathrm{~g}$ dry weight. Interestingly, when single leaves from individual plants were analyzed, the content was found to be significantly higher in younger leaves. In the same study, the four compounds were also quantified in leaves of $B$. daigremontianum and B. delagoense [24].

\section{Flavonoids}

A number of flavonoids have been identified in B. pinnatum. They include numerous flavonol derivatives (14-35), mainly quercetin and kaempferol glycosides, as well as a few flavone glycosides, such as acacetin, luteolin, and diosmetin glycosides (36-40) (O Table 2, Fig. 2) [13,25-36]. In addition, epigallocatechin-3-0syringate (41) [36] and an ethenylamino-substituted anthocyanidin with a biogenetically unlikely structure [37] have been reported.

To our knowledge, no flavonoids have been reported from B. daigremontianum, but quercetin (27), 4'-0-methylherbacetin (42), and 3,5,7,8,4'-pentahydroxy-3'-methoxyflavone (43) have been isolated from the whole plants of B. delagoense [38] ( $\mathbf{~ F i g . 2 ) . ~}$

\section{Further isoprenoids}

Several triterpenes, including $\alpha$-amyrin, $\beta$-amyrin [39], $\alpha$ amyrin- $\beta$-D-glucopyranoside [40], bryophollone (44), bryophynol (45), $18 \alpha$-oleanane, $\Psi$-taraxasterol [41], taraxerone, glut-5 (6)-en-3-one, and $3 \beta$-friedelanol [35], were reported from B. pinnatum. The plant was also shown to contain various phytosterols, such as bryophyllol (46) [41], stigmast-24-enol, (24 S)-stigmast25-enol, 25-methylergost-24(28)-enol, clerosterol, 24-epiclerosterol, $\beta$-sitosterol, 22-dihydrobrassicasterol, stigmasterol, campesterol, isofucosterol, codisterol, 24-ethyl-desmosterol, ergosta-5,24(28)-dienol, 25-methylergosta-5,24(28)-dienol [42], 24ethyl-25-hydroxycholesterol [41], peposterol, avenasterol, (24R)-stigmasta-7,25-dienol, (24 S)-stigmasta-7,25-dienol [42], and stigmast-4,20(21),23-trien-3-one (47) [40]. 
Table 1 Bufadienolides isolated from B. pinnatum, B. delagoense, B. daigremontianum, and the hybrid B. daigremontianum x tubiflorum.

\begin{tabular}{|c|c|c|c|}
\hline Compound & Species & Plant part & References \\
\hline \multirow[t]{4}{*}{ Bersaldegenin-1-acetate (1) } & B. daigremontianum & Leaves, aerial parts & {$[13,20,23]$} \\
\hline & B. daigremontianum x tubiflorum & Leaves & {$[17]$} \\
\hline & B. pinnatum & Leaves & [13] \\
\hline & B. delagoense & Whole plant & [14] \\
\hline \multirow[t]{2}{*}{ Bersaldegenin-3-acetate (2) } & B. daigremontianum & Leaves, aerial parts & {$[13,20,23]$} \\
\hline & B. pinnatum & Leaves, whole plant & {$[13,16]$} \\
\hline \multirow[t]{4}{*}{ Bersaldegenin-1,3,5-orthoacetate (3) } & B. daigremontianum & Leaves, aerial parts & {$[13,19,20,23]$} \\
\hline & B. daigremontianum $\times$ tubiflorum & Leaves & {$[17,18]$} \\
\hline & B. pinnatum & Leaves & [13] \\
\hline & B. delagoense & Flowers & [14] \\
\hline \multirow[t]{4}{*}{ Bryophyllin A (= bryotoxin C) (4) } & B. daigremontianum & Flowers, leaves/stems & [13] \\
\hline & B. pinnatum & Leaves & {$[13,16]$} \\
\hline & B. pinnatum & Flowers, leaves/stems, roots & {$[15,22]$} \\
\hline & B. delagoense & Flowers, leaves/stems, roots & {$[12,14,15]$} \\
\hline Bryophyllin B (5) & B. pinnatum & Leaves, whole plant & [21] \\
\hline Bryophyllin C (6) & B. pinnatum & Leaves & [16] \\
\hline \multirow[t]{3}{*}{ Bryotoxin A (7) } & B. daigremontianum $\times$ tubiflorum & Roots & [15] \\
\hline & B. pinnatum & Roots & {$[15]$} \\
\hline & B. delagoense & Flowers, leaves/stems, roots & {$[11,14,15]$} \\
\hline \multirow[t]{4}{*}{ Bryotoxin B (8) } & B. daigremontianum & Flowers, leaves/stems & [15] \\
\hline & B. daigremontianum $\times$ tubiflorum & Flowers, leaves/stems, roots & [15] \\
\hline & B. pinnatum & Flowers, leaves/stems, roots & [15] \\
\hline & B. delagoense & Flowers, leaves/stems, roots & {$[12,15]$} \\
\hline \multirow[t]{2}{*}{ Daigremontianin (9) } & B. daigremontianum & Aerial parts & {$[19,20,23]$} \\
\hline & B. daigremontianum $\times$ tubiflorum & Leaves & {$[17,18]$} \\
\hline Daigredorigenin-3-acetate (10) & B. daigremontianum & Aerial parts & {$[20,23]$} \\
\hline Kalantuboside A (11) & B. delagoense & Whole plant & [14] \\
\hline Kalantuboside B (12) & B. delagoense & Whole plant & [14] \\
\hline Methyl daigremonate (13) & B. daigremontianum x tubiflorum & Leaves & [17] \\
\hline
\end{tabular}

From B. daigremontianum, glutin-5(6)-en-3 $\beta$-ol, stigmasterol, and a mixture of $\alpha$ - and $\beta$-amyrin have been isolated [43]. Glutinol and friedelin have been identified by mass spectrometry as the major triterpenoids in the leaf wax [44]. The wax further contains glutanol, glutinol acetate, epifriedelanol, germanicol, and $\beta$ amyrin [45]. Finally, $\beta$-sitosterol-3-0-glucoside, stigmasterol-3O-glucoside, a megastigmane sesquiterpene, tubiflorone (48) [38], and two cardenolides, kalantubolides A (49) and B (50) [14], were isolated from $B$. delagoense. The latter compounds possess a 1,3,5-orthoacetate function that is also found in many bufadienolides of the genus Bryophyllum. Kalantuboside B differs from kalantuboside A by a biogenetically unusual location of the carbonyl group in the lactone ring ( Fig. 3 ).

\section{Miscellaneous metabolites}

2(9-Decenyl)-phenanthrene and 2-(9-undecenyl)-phenanthrene [41] were obtained as a mixture from the leaves of $B$. pinnatum and identified by GC-MS. More recently, a nitrogen containing derivative (6-[8-(ethenylamino)phenanthren-2-yl]hex-5-yn-2one) was also obtained [46]. However, it must be pointed out that the structure reported for the latter compound is biogenetically not plausible.

A lignan glycoside, bryophylluside (51), was isolated from the herbs of B. pinnatum [26]. Phenolic acid derivatives identified in B. pinnatum include gallic acid [36], syringic acid $\beta$-D-glucopyranosyl ester, 4'-O- $\beta$-D-glucopyranosyl-cis- $p$-coumaric acid [13], and, according to a previous review, ferulic acid, syringic acid, caffeic acid, $p$-coumaric acid, protocatechuic acid, 4-hydroxy-3methoxy-cinnamic acid, and p-hydroxybenzoic acid [2]. 4-OEthylgallic acid, syringic acid, vanillic acid, methyl gallate, 3,4-di- methoxyphenol, phloroglucinol, and 3,4-dihydroxyallylbenzene were reported in $B$. delagoense [38].

The presence of $n$-alkanols and $n$-alkanes, such as $n$-hentriacontane and $n$-tritriacontane [39], bryophollenone (52) [41], and a minor constituent, 1 -octen-3-ol-O- $\alpha$-L-arabinopyranosyl$(1 \rightarrow 6)-\beta$-D-glucopyranoside [47], have been reported in B. pinnatum. In B. daigremontianum, ferulate esters of $C_{22}-C_{30}$ alcohols were found in the roots, and triacontanol was detected in the leaves [48]. Taurolipid C (53) was found in B. delagoense [14] (๑ Fig. 3).

B. pinnatum was shown to contain large amounts of malic acid [13]. Other carboxylic acids include, according to a previous review, oxalic acid, citric acid, isocitric acid, cinnamic acid, succinic acid, oxaloacetate, and phosphoenolpyruvate [2]. In addition, the fatty acids palmitic, stearic, arachidic, and behenic acids [49], as well as various vitamins (ascorbic acid, riboflavin, thiamine, niacin, pyridoxine), were reported [2]. The rare vitamin E congeners $\beta$-, $\gamma$-, and $\delta$-tocomonoenols were identified in the leaves of $B$. daigremontianum, together with the widespread $\alpha-, \gamma$ - and $\delta$ tocopherols [50].

\section{Ethnomedical Uses \\ $\nabla$}

B. pinnatum has been widely used in traditional medicine of tropical regions where the plants grow spontaneously, such as Madagascar, Nigeria, Trinidad and Tobago, India, Indonesia, Philippines, Indo-China, and Brazil. Leaves and stems taste bitter and, due to their astringent effects, are effective against diarrhea, flatulence, and vomiting [2]. In Trinidad and Tobago, they are used to 


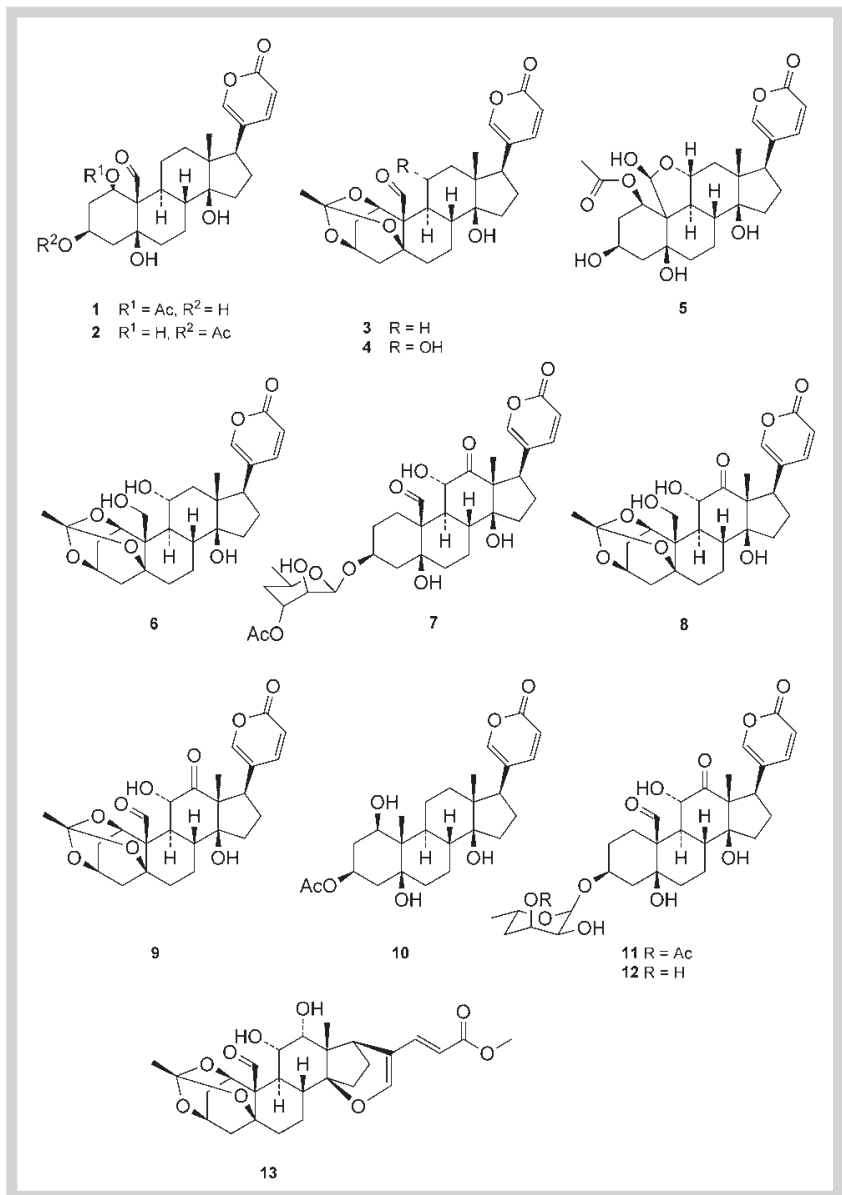

Fig. 1 Structures of bufadienolides from B. pinnatum, B. daigremontianum, B. delagoense, and B. daigremontianum x tubiflorum.

treat several diseases and afflictions, such as hypertension and kidney and urinary disorders [51]. Herbalists in Nigeria use an aqueous leaf extract for the treatment of cough and in the prophylaxis of asthma [52]. In India, the leaves are employed as a hepatoprotective herb to treat jaundice [53], and have also been recommended for the treatment of wounds, bruises, and insect bites $[54,55]$. Leaf preparations are used as an antipyretic and for treatment of malaria in Africa, Asia, and Latin America [56]. Further traditional uses with the corresponding countries have been listed in [3].

\section{Bryophyllum pinnatum in Anthroposophic Medicine $\nabla$}

AM is an integrative multimodal medical system that was developed by the Austrian philosopher Rudolf Steiner (1861-1925) and the Dutch medical doctor Ita Wegman (1876-1943). AM is currently practiced in 80 countries worldwide.

In 1921, the first anthroposophic hospital in Arlesheim, Switzerland, was established by Ita Wegman. AM is practiced by physicians who are fully trained and qualified in university medicine by integrating conventional skills and methods with a holistic understanding of man and nature. From this point of view, the understanding of the human being in his entirety means the acceptance of a three-system organization with a physical body, the soul, and the spirit. This holistic view of the human being leads to an understanding of health and illness that differs from conventional medicine, and to treatments that are specifically adapted to each individual.

Bryophyllum plants have the unique ability to let new plantlets grow from their leaves, thereby suggesting, according to anthroposophic concepts, a strong vegetative force and great vitality. Additionally, flower formation is somehow displaced to the leaves, as demonstrated by the distribution of anthocyanins, which are normally present in flowers, and are responsible for the reddish and purple patterns on the leaves. Furthermore, the plant does flower under favorable conditions only.

From the perspective of AM, B. pinnatum is therapeutically indicated if the so-called astral and etheric bodies separate too much from each other. This means that the processes linked to psychic qualities, such as emotions, and the physiological processes are not well-balanced, which disturbs the basis for the healthy state of a patient. B. pinnatum is supposed to reunite these two parts of the human organization, thereby restoring holistic balance. Based on this principle, $B$. pinnatum has historically been used to treat inner restlessness and anxiety, and, therefore, was also called "herbal valium" due to its sedative properties $[57,58]$.

In $1921, B$. pinnatum preparations were initially recommended by Rudolf Steiner as AMs to treat "hysteria" [59]. Steiner described hysteria as the condition in which the spiritual and emotional energy is not capable anymore to fully regulate normal physical functions [60]. Later, in 1970, Dr. Werner Hassauer (1928-1993), a German gynecologist, introduced B. pinnatum as a tocolytic agent to prevent premature labor in an AM hospital (see below) [61].

\section{Preparations and application}

A large multicenter observational study was performed involving 38 German physicians collaborating in the Evaluation of Anthroposophic Medicine (EvaMed) network. Over 6 years, a total of 4038 prescriptions were recorded in the EvaMed data bank and showed a broad indication range [62]. B. pinnatum preparations are produced by Weleda AG, while WALA Heilmittel GmbH focuses on B. daigremontianum.

The use of $B$. pinnatum preparations is described in the German Commission C monographs. In Switzerland, B. pinnatum preparations are authorized by the Swiss Agency for therapeutic products (Swissmedic) as a medicinal product without any indication. B. pinnatum is currently used for the treatment of premature labor and for some other medical conditions, such as sleep disorders induced by restlessness, anxiety, pain induced by vital weakness, and recurrent inflammation in the metabolic system [63]. Complex anthroposophic preparations, such as B. pinnatum Mercurio cultum or Argento cultum contain plants which were fertilized with the corresponding homeopathic diluted metal (quicksilver or silver) [62]. These preparations are primarily used to regulate metabolic processes with or without concomitant psychological symptoms (e.g., restlessness and sleep disorders). The combination of $B$. pinnatum and Conchae (calcium carbonate from oyster shell) is also used to harmonize rhythm and is prescribed to patients suffering from difficulty falling asleep, restlessness, excitation, and exhaustion [64]. B. pinnatum preparations from Weleda AG are available in different galenical forms such as powder, tablets, drops, and ampoules. Globuli velati (sucrose globules coated with a syrup containing homeopathic dilutions) are commercialized by Wala Heilmittel GmbH.

Very recently, an online survey in Switzerland showed that in gynecology and obstetrics, B. pinnatum (50\% tablets) is being 
Table 2 Flavonols and flavones isolated from B. pinnatum.

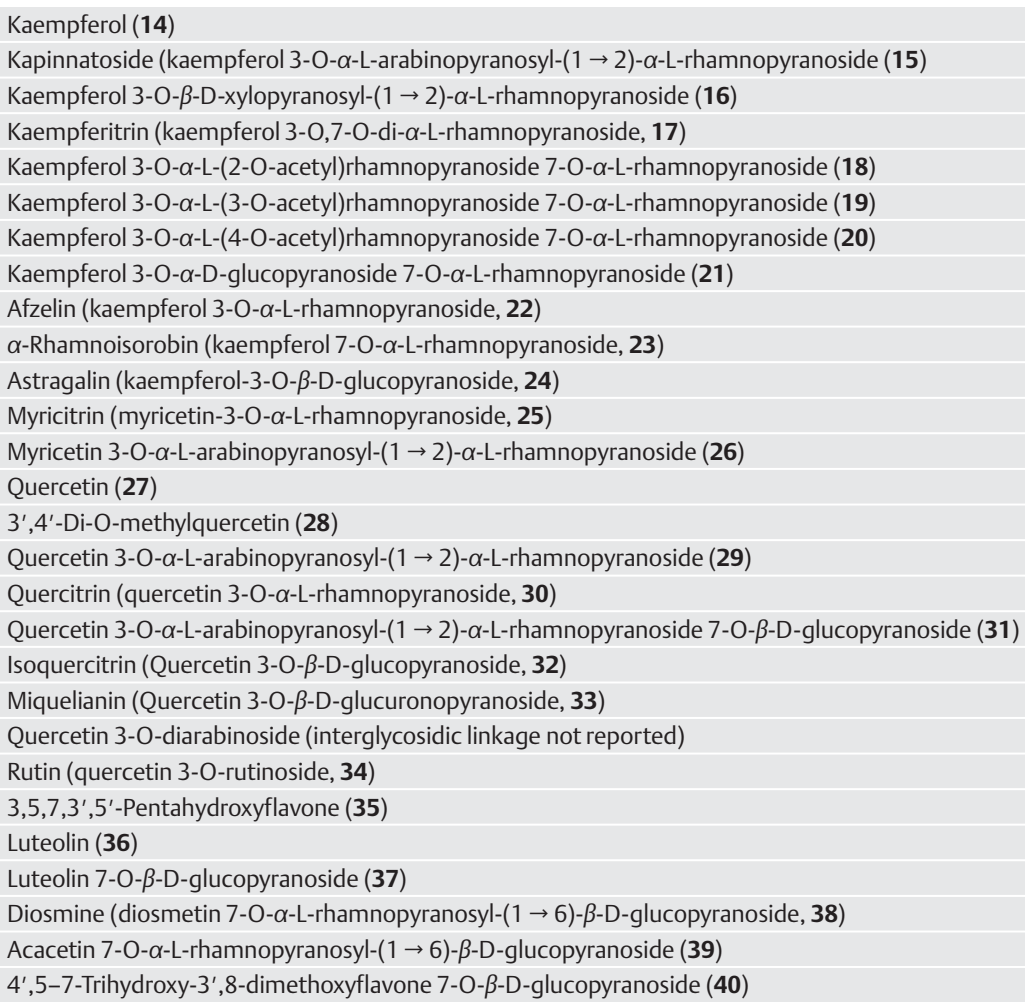

prescribed for pregnant women in the case of premature labor, and against restlessness and hyperactive bladder. With twothirds of the patients being treated at the University Hospital of Zurich, this work showed that $B$. pinnatum is a herbal product whose use is no longer confined to the AM, but has been integrated in conventional settings [65].

\section{Pharmacological and Clinical Activities Related to Anthroposophic Medicine}

B. pinnatum has been used in AM to treat various disorders caused by hyperactive conditions. In vitro and in vivo studies that have been performed are summarized below. More detailed information about the respective studies is provided as Supporting Information (Table 2 S, Supporting Information).

\section{Tocolysis}

B. pinnatum preparations have been used as a tocolytic agent since years, and several studies have been performed. The German gynecologist Dr. Hassauer showed that the tocolysis with B. pinnatum $5 \%$ i.v. infusion and $50 \%$ trituration orally was well tolerated, and successful in $84 \%$ of the women. The treatment allowed him also to decrease the dosage of the beta-agonist fenoterol, or even replace it [61]. In a retrospective study with 170 pregnant women, the tocolytic effect of $B$. pinnatum was investigated. Group A was treated with B. pinnatum $5 \%$ infusion followed by the oral treatment with $50 \%$ trituration. The treatment in group B also started with B. pinnatum $5 \%$ infusion and due to an inadequate effect after $2 \mathrm{~h}$, women additionally received fenoterol i.v. or p.o. followed by oral treatment with B. pinnatum $50 \%$ trituration. $B$. pinnatum showed a positive outcome comparable

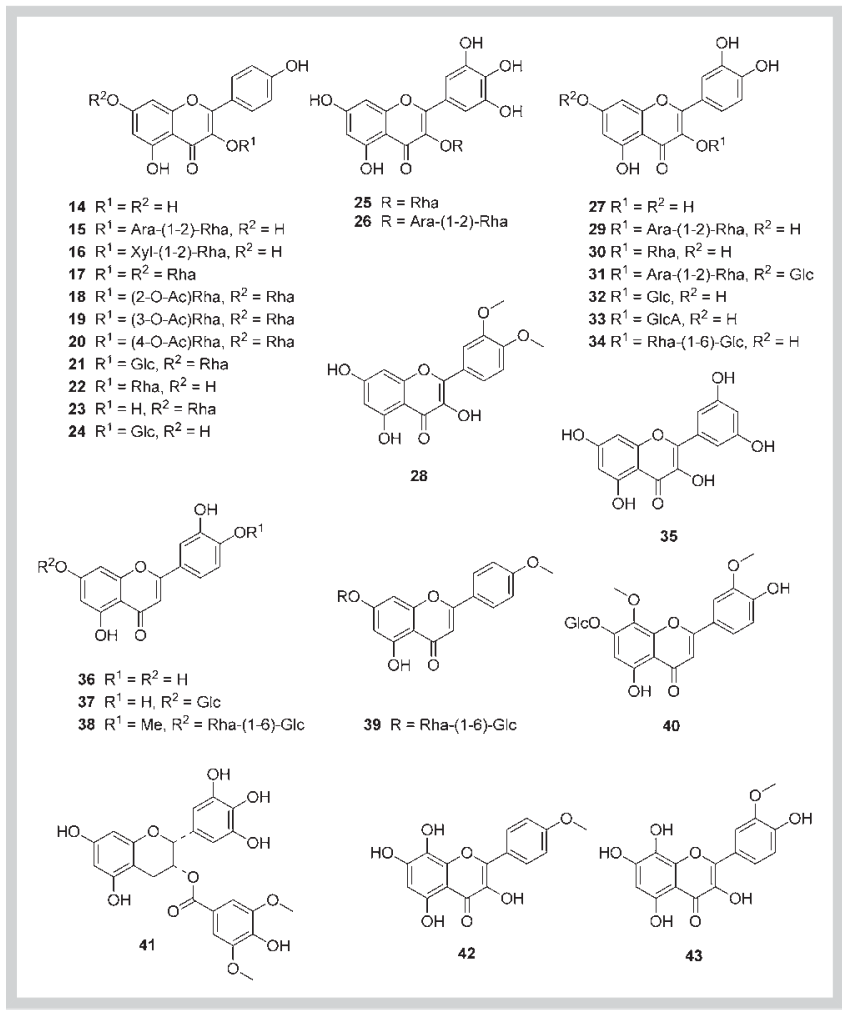

Fig. 2 Structures of flavonoids from B. pinnatum and B. delagoense. 


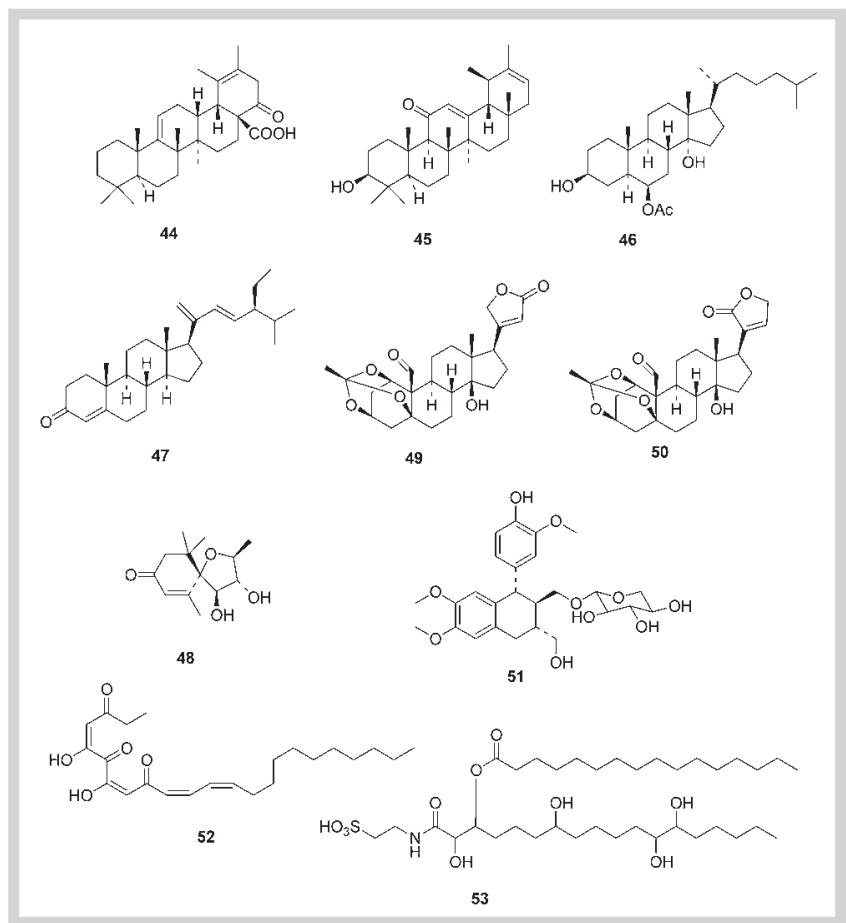

Fig. 3 Structures of miscellaneous compounds from B. pinnatum, B. daigremontianum, and B. delagoense.

to fenoterol, and no undesired effects were recorded [66]. From 1977 to 2000, a total of 1622 deliveries were documented and evaluated by Dr. Istvan Vilàghy, a gynecologist who practiced in Switzerland. In this study, data from 253 pregnant women who needed a tocolytic therapy, and 29 premature deliveries were analyzed. In the period from 1977 to 1983, fenoterol was used to prevent premature labor resulting in an incidence of premature deliveries of $6.2 \%$. In the following years, Dr. Vilàghi integrated B. pinnatum in the treatment of premature labor. From 1990 to 2000 , he treated pregnant women almost exclusively with $B$. pinnatum 33\% dilution. When B. pinnatum was used for the treatment of premature labor, the incidence of premature deliveries decreased to $1.1 \%$ [67].

In a retrospective matched-pairs study, the tolerability and tocolytic activity of i.v. administered B. pinnatum $5 \%$ was compared with beta-agonists (fenoterol or hexoprenaline) in a total of 67 pregnant women. This study demonstrated similar maternal and neonatal outcomes in both treatment groups. However, maternal adverse effects (palpitation, dyspnea) were significantly reduced, and the use of corticosteroids and antibiotics was lower in the group treated with $B$. pinnatum. Neonatal outcomes and morbidity rates were similar or superior in the B. pinnatum treatment group [68]. In addition, a prospective, randomized clinical trial assessed the efficacy and safety of $B$. pinnatum $50 \%$ chewable tablets versus a currently used calcium antagonist, nifedipine, for the treatment of premature contractions. A total of 27 pregnant women were included before the study was interrupted due to slow recruitment. Nevertheless, data showed that treatment with $B$. pinnatum as well as treatment with nifedipine led to significant decreases in the number of contractions/h. The neonatal outcome did not differ between the two groups [69].

The tocolytic activity of $B$. pinnatum was confirmed in an in vitro study in comparison to fenoterol. B. pinnatum aqueous leaf ex- tract $\left(10^{4} \mathrm{mg} / \mathrm{L}\right)$ led to a dose-dependent inhibition of spontaneous human myometrium contractions, although the contraction frequency increased. The extract also showed a relaxant effect on oxytocin-induced contractions. Fenoterol decreased myometrial contractions and frequency [70]. Subsequently, the in vitro effects on spontaneous contractions in myometrial strips was investigated with $B$. pinnatum leaf press juice, and with three fractions of $B$. pinnatum extract, labelled as flavonoid, bufadienolide, and cinnamic acid fractions. After five spontaneous muscle contractions, $2 \mu \mathrm{L}$ of the leaf press juice (undiluted) and fractions ( $1 \%, 2 \%, 5 \%, 10 \%$, undiluted) were added to the organ bath chamber. The effects on the AUC, amplitude, and frequency of the contractions were measured. The leaf press juice significantly reduced the AUC to $82 \%$ and rapidly increased the frequency to $128 \%$ after the first application. Reduction of the amplitude to $78 \%$ was statistically significant after the second application. The fraction enriched in flavonoids (undiluted) significantly reduced the AUC to $51 \%$ and caused a rapid and large increase in frequency to $557 \%$ after the first application. The amplitude was reduced to $70 \%$ after the second application. The two other fractions did not significantly affect the AUC and the amplitude, but increased the contraction frequency more than the control [71]. The mechanism behind the tocolytic effect of $B$. pinnatum was further investigated using human myometrial cells. In hTERT-C3 cells, leaf press juice led to a dose-dependent inhibition of the oxytocin-induced increase of intracellular $\left[\mathrm{Ca}^{2+}\right]\left(\left[\mathrm{Ca}^{2+}\right]_{\mathrm{i}}\right.$, $\left.\mathrm{IC}_{50}=0.94 \%\right)$. Comparable data were obtained in M11 cells. Furthermore, in hTERT-C3 cells kept under $\mathrm{Ca}^{2+}$-free conditions, press juice significantly inhibited the oxytocin-induced increase of intracellular $\left[\mathrm{Ca}^{2+}\right]$. Hence, the observed inhibitory effect was assumed to be independent of the extracellular calcium concentration. In addition, the effect of leaf press juice was investigated in SH-SY5Y human neuroblastoma cells, which are known to express voltage-dependent L-type $\mathrm{Ca}^{2+}$ channels. The $\left[\mathrm{Ca}^{2+}\right]_{i}$ response to $\mathrm{KCl}$ was not reduced by the press juice, but delayed, suggesting that the voltage-dependent calcium influx through the channels was restricted [72].

\section{Overactive bladder (OAB) syndrome}

$\mathrm{OAB}$ is a symptomatic diagnosis that has been defined by the International Continence Society (ICS) as urinary urgency, with or without urge incontinence, usually with frequency and nocturia, after the exclusion of urinary tract infection (UTI) or other obvious pathologies [73]. Current pharmacotherapy of OAB includes drugs with various modes of action. Muscarinic receptor antagonists are the first-line pharmacotherapy for $\mathrm{OAB}$ and urinary incontinence. A beta3-agonist with proven clinical benefits was recently registered in several countries, but only limited data on long-term efficacy and safety are currently available. Besides, other drugs including calcium antagonists, serotonin and noradrenaline reuptake inhibitors, and estrogens as well as intravesical injection of botulinum toxin are used to mitigate symptoms of OAB.

In a prospective, randomized, double-blind, placebo-controlled study, 20 postmenopausal women suffering from OAB or urgency-dominant mixed urinary incontinence (MUI) were treated with $B$. pinnatum $50 \%$ chewable tablets or placebo. The women took $3 \times 2$ blinded capsules daily during 8 weeks. In a total of 15 weeks, they had 5 visits and were ask to fill out 2-day bladder diaries and answer 2 questionnaires, the King's Health Questionnaire (KHQ) and the International Consultation on Incontinence Modular Questionnaire for OAB (ICIQ-OAB). After treatment, a 
positive trend for $B$. pinnatum was observed relatively to the placebo. The primary endpoint, the micturition frequency $/ 24 \mathrm{~h}$, was reduced from 9.5 before to 7.8 after the treatment $(\mathrm{p}=0.064)$. The quality of life $(\mathrm{QoL})$ was comparable in the $B$. pinnatum and placebo group [74].

The effect of $B$. pinnatum leaf press juice on porcine detrusor muscle contractility was investigated in an organ bath chamber, in comparison with oxybutynin as a reference drug. Press juice ( $5 \%$ in the chamber) significantly inhibited detrusor contractility induced by electrical field stimulation (EFS) by $74.6 \%$ compared to the control. In addition, the press juice $(10 \%)$ had a significant relaxant effect $(18.7 \%)$ on carbachol-induced contractions. The leaf press juice showed good activity, although oxybutynin had a more potent inhibitory and relaxing effect on the detrusor muscle [75].

The effect of leaf press juice and different fractions of $B$. pinnatum on electrically induced porcine detrusor contractility was investigated in further experiments. The inhibitory properties of leaf press juice were confirmed, even though an initial stimulatory effect was observed. A flavonoid-enriched fraction reduced muscle contractility in a concentration- and time-dependent manner, resulting in a maximum inhibition of $78.7 \%$ at a test concentration of $1 \mathrm{mg} / \mathrm{mL}$ after $77 \mathrm{~min}$. The lipophilic fraction containing the bufadienolides had no inhibitory effect on contractility at the investigated concentrations. However, due to a poor solubility of the lipophilic fraction test concentrations were significantly lower. An unexpected inhibitory effect was found in the polar fraction that contained substances that were not retained on a HP-20 column. Finally, this effect could be explained by a decreased $\mathrm{pH}$ in the organ bath chamber due to the presence of a large amount (17.8\%) of L-malic acid in this fraction [76].

\section{Sleep and neurological disorders}

In a prospective, multicenter, observational study, 49 pregnant women suffering from sleep disorders were treated with $B$. pinnatum 50\% chewable tablets. The women took 3-8 tablets per day and were asked to complete questionnaires before and after the 14-day treatment. The number of wake-ups and the subjective quality of sleep were significantly improved, and women felt less sleepy during the day. However, a prolongation of sleep duration and reduction in the time to fall asleep was not achieved [77]. In a further study, the effect of $B$. pinnatum on sleep quality was assessed in 20 cancer patients. Treatment ( 3 weeks) with chewable tablets (mostly $2 \times 2$ tablets per day) resulted in a decrease of the Pittsburg Sleep Quality Index (PSQI) from 12.2 to 9.1, and sleepiness was slightly reduced [78].

The behavioral neuropharmacology of $B$. pinnatum aqueous leaf extract was investigated in mice, and neurosedative, CNS depressant, and anxiolytic activities were found. Furthermore, a dosedependent muscle relaxant effect of the aqueous extract was observed, which was comparable to diazepam. Therefore, a GABAergic activity has been suggested for B. pinnatum [79]. Some of these neuropharmacological effects were tested in Swiss mice applying a methanolic fraction. The GABA content in the brain was estimated after i.p. administration, and the methanolic fraction led to an increase in brain GABA concentration [80].

The compounds responsible for the neurological activity are not definitively known, but a neurosedative effect of bersaldegenin1,3,5-orthoacetate (3) was demonstrated in mice, whereby strongly sedative activity was observed with doses of $0.1-$ $0.5 \mathrm{mg} / \mathrm{kg}$ b.w. However, higher doses resulted in paralysis and muscle contractions [23].

\section{Other Biological and Pharmacological Activities} $\nabla$

Additional activities have been investigated both in vitro and in vivo. Some of the described activities correspond to uses in traditional medicine, but only a few studies in humans have been reported. A detailed description of the settings and outcomes can be found in Table $3 \mathrm{~S}$, Supporting Information.

\section{Antimicrobial activity}

In vitro experiments using the agar-well diffusion method demonstrated the sensitivity of several bacteria and fungi to hot water and methanolic extracts as well as to flavonoids of $B$. pinnatum [81,82]. Several compounds, including a phenanthrene [46], $\alpha$-rhamnoisorobin (23), and further kaempferol rhamnosides $(\mathbf{1 7}, \mathbf{1 9 - 2 2})$ [28], showed antimicrobial activity.

\section{Antileishmanial activity}

Leishmaniasis comprises diseases that are caused by protozoan parasites belonging to over 20 Leishmania species. The protozoa are transmitted by the bite of female phlebotomine sandflies. Treatment of a cutaneous leishmaniasis patient with an aqueous leaf extract of $B$. pinnatum stopped growth and led to a slight decrease of the active lesion. At the end of the 14-day treatment period, the toxicological parameters of the patient's serum were within the reference range [83]. In mice, the effect of an aqueous B. pinnatum extract was investigated after oral (by intragastric intubation), i.v., i.p., and topical (by rubbing the lesion site) administration. The oral treatment was most effective and was able to prevent or delay the onset of lesions in a sustained manner. Additionally, after oral, i. p., or topical application, titers of a parasite-specific antibody ( $\operatorname{IgG}$ ) were reduced to $20 \%$ when compared with untreated mice [84]. Interestingly, the activity was abolished in vitro and in vivo by cotreatment with $\mathrm{N}$-monomethylarginine, an inhibitor of inducible NO synthase and, hence, of NO production. The authors concluded that the protective activity was possibly not due to a direct effect on the parasite, but rather to the increase of NO production of macrophages [85]. Subsequent investigations revealed that flavonoids were involved in the antileishmanial activity of the aqueous extract. Quercitrin (30) and a quercetin diglycoside (29) had the highest in vitro antileishmanial activity and low cytotoxicity. It has been suggested that the aglycone quercetin is relevant for the antileishmanial activity, since the corresponding kaempferol glycosides (15 and 22) were significantly less active [27,34]. Orally administered quercetin and quercetin glycosides were able to stop the growth of lesions in mice. An explanation for the comparable in vivo activity of aglycone and glycosides could be that the same active metabolites are produced upon oral administration [86].

\section{Insecticidal activity}

Several bufadienolides isolated from $B$. pinnatum and B. daigremontianum $\mathrm{x}$ tubiflorum were tested in an in vitro assay using 3rd instar larvae of the silkworm. Larvae were cultured on an artificial diet and further put into petri dishes containing the test samples (added to $1 \mathrm{~g}$ of the diet). The mortality rate was determined after $24 \mathrm{~h}$. Daigremontianin (9), bryophyllin A (4), bryophyllin C (6), and bersaldegenin-1,3,5-orthoacetate (3) showed $\mathrm{LD}_{50}$ values of $0.9,3,5$, and $16 \mu \mathrm{g} / \mathrm{g}$ of diet, respectively, whereas bersaldegenin-1-acetate (1) and bersaldegenin-3-acetate (2) showed no insecticidal activity. These results suggest that the 1,3,5-orthoacetate moiety is essential for the insecticidal effect $[16,17]$. 


\section{Cytotoxic and antitumor promoting activity}

An in vitro study demonstrated a concentration-dependent inhibition of human cervical cancer cell growth when B. pinnatum chloroform extract, and a fraction containing steroidal glycosides, alkaloids, and steroids were tested. The fraction was more potent than the extract and showed proapoptotic activity. In contrast, higher activity was observed for the extract against human papillomavirus (HPV), which plays a pivotal role in the development of cervical cancer [87]. The butanol-soluble fraction of an ethanolic extract of fresh $B$. delagoense plants showed antiproliferative activity [88] in several cell lines via a modulation of the mitotic cell division. More recently, the water-soluble fraction of the same extract was shown to cause cell cycle arrest, and to induce senescence in lung cancer A549 cells. At doses of $10 \mathrm{mg}$ and $100 \mathrm{mg} / \mathrm{kg}$ b.w. 5 times per week for 6 weeks, the fraction also reduced tumor growth in nude mice [89].

In several studies, a cytotoxic effect of bufadienolides from Bryophyllum species was found. Bryophyllin A (4) showed potent cytotoxicity in human lung carcinoma A- 549 cells, KB cells, and colon HCT-8 tumor cells with $\mathrm{ED}_{50}$ values of 10,14 , and $30 \mathrm{ng} / \mathrm{mL}$, respectively. Bersaldegenin-3-acetate (2) mainly demonstrated an effect against HCT-8 cells $\left(E_{50}=10 \mathrm{ng} / \mathrm{mL}\right)$ and bryophyllin B showed cytotoxicity against $\mathrm{KB}$ cells with an $\mathrm{ED}_{50}$ value of $<80 \mathrm{ng} / \mathrm{mL}[21,22]$. A series of five bufadienolides and two cardenolides isolated from $B$. delagoense showed significant cytotoxic activity against A549, Cal-27, A2058, and HL 60 cancer cell lines. Kalantuboside B (12) and bersaldegenin-1,3,5-orthoacetate (3) were the most potent compounds against A2058 and HL-60 cells with $\mathrm{IC}_{50} \mathrm{~S}$ of $0.01 \mu \mathrm{M}$ [14].

Besides cytotoxic properties, bufadienolides also showed antitumor promoting activity. Five compounds isolated from B. pinnatum and B. daigremontianum $\mathrm{x}$ tubiflorum inhibited EpsteinBarr virus early antigen (EBV-EA) activation. The 1,3,5-orthoacetate moiety appeared to be important for the chemopreventive activity [18].

\section{Antioxidant activity}

Extracts and flavonoids of B. pinnatum showed free radical scavenging activity in the 2,2-diphenyl-1-picrylhydrazyl (DPPH) free radical assay. Particularly active were $\alpha$-rhamnoisorobin (23) $\left(\mathrm{IC}_{50}=0.71 \mu \mathrm{g} / \mathrm{mL}\right)[28]$ and quercetin 3-O- $\alpha$-L-arabinopyranosyl-(1 $\rightarrow 2)$ - $\alpha$-L-rhamnopyranoside (29) $\left(\mathrm{EC}_{50}=1.41 \mu \mathrm{g} / \mathrm{mL}\right)$ [90].

\section{Immunomodulatory activity and antiallergic effects}

B. pinnatum leaf press juice produced an in vitro antihistaminic effect in the guinea pig ileum and prevented histamine-induced bronchoconstriction in guinea pigs in vivo. Flavonoids were thought to be responsible for the selective and competitive inhibition of the $\mathrm{H}_{1}$ receptor [91]. In addition, aqueous leaf extracts possessed an antiasthmatic effect by successfully protecting guinea pigs from histamine-induced preconvulsive dyspnea. The reduction of coughing bouts in guinea pigs treated with this extract confirmed its antitussive properties [52].

Mice receiving daily oral treatment with $B$. pinnatum aqueous leaf extracts during a 14-day sensitization (ovalbumin, OVA) period were protected from fatal anaphylactic shock. Quercitrin (30) had a protective effect in $75 \%$ of the animals and appeared to be important for the antianaphylactic effect of the extract. Furthermore, the aqueous leaf extract reduced eosinophilia as well as IL-5, IL-10, and TNF- $\alpha$ cytokine production [92]. In addition, the aqueous extract of $B$. pinnatum and quercetin, but not quercitrin, inhibited the development of allergic airway inflammation and airway hyperresponsiveness in mice. It is assumed that the inhibition of mast cell degranulation and reduction of TNF- $\alpha$ levels were involved in the antiallergic effect [93].

\section{Anti-inflammatory activity}

In Wistar rats, oral administration of $400 \mathrm{mg} / \mathrm{kg}$ b.w. of an aqueous leaf extract of $B$. pinnatum significantly reduced paw edema [94]. This result was confirmed in another independent study that showed a significant reduction of acute inflammation by the aqueous extract ( $400 \mathrm{mg} / \mathrm{kg}$ b.w.; p.o.) and a new constituent, stigmast-4,20(21),23-trien-3-one (47) $(300 \mathrm{mg} / \mathrm{kg}$ b.w.; p.o.), of $87.3 \%$ and $84.5 \%$, respectively. The authors concluded that this steroidal compound was mainly responsible for the anti-inflammatory activity [40]. However, no data were shown to demonstrate that this steroid (isolated from a $95 \%$ ethanolic extract) was also present in the water extract. In a recent study, the inhibitory effect of a B. pinnatum ethanolic extract was investigated in Swiss albino mice on ear edema induced by various irritant agents such as croton oil, capsaicin, and phenol. Depending on the irritant agent, extract doses of $0.1 \mathrm{mg} /$ ear or $0.5 \mathrm{mg} / \mathrm{ear}$ showed significant inhibition [30]. Also, an aqueous extract of the flowers and the quercetin diglycoside 29 inhibited croton oil-induced ear edema and reduced leucocyte migration in carrageenan-induced pleurisy in mice. The extract and 29 both reduced the TNF- $\alpha$ concentration in the pleural exudate. Compound 29 also showed cyclooxygenase (COX) inhibition in an enzymatic assay [95].

\section{Antiulcer activity}

The pretreatment with leaf press juice did not prevent the development of histamine-induced ulcerations in guinea pigs [91]. However, a methanolic fraction of B. pinnatum possessed antiulcer activity in rats. The development of different types of acute gastric ulcers was significantly inhibited after i.p. pretreatment at doses of 100 or $300 \mathrm{mg} / \mathrm{kg} \mathrm{b}$. w. Additionally, the healing of acetic acid-induced gastric ulcers was improved [54]. In another study with lower doses (10-40 mg/kg b.w.), inhibition of indomethacin-induced gastric ulceration was also observed [96].

\section{Antinociceptive/analgesic activity}

Antinociceptive activity of B. pinnatum was investigated in mice. Mice were treated with an aqueous extract prior to exposure to a heat-induced nociceptive pain stimulus (hot plate). In another assay, the abdominal contractions triggered by i.p. injection of $3 \%$ acetic acid were observed. In both experimental setups, the aqueous extract provided significant protection against the nociceptive stimulus compared to diclofenac [94]. In addition, the analgesic potential of the aqueous extract, a methanolic fraction, and a steroidal compound of $B$. pinnatum was examined. Using the chemical method described above, the aqueous extract and stigmast-4,20(21),23-trien-3-one (47) significantly reduced the number of contractions by $80.16 \%$ and $75.72 \%$, respectively. The methanolic fraction also showed a significant reduction of contractions $[40,80]$. At doses of $100-300 \mathrm{mg} / \mathrm{kg}$ b.w., the aqueous leaf extract increased the pain threshold in rats in the hot plate assay, and reduced phenylbenzoquinone-induced writhing in mice [97]. Antinociceptive properties together with anti-inflammatory activity have been recently reported for an aqueous extract of the flowers. The extract and the quercetin glycoside $\mathbf{2 9}$ significantly reduced the number of acetic acid-induced writhings in mice [95]. 


\section{Hepatoprotective activity}

The juice of B. pinnatum has been used to treat jaundice in Indian folk medicines. The protective effect of a concentrated press juice and of an ethanolic extract of the marc (left after expressing the juice) against $\mathrm{CCl}_{4}$-induced hepatotoxicity was examined in vitro and in vivo. The leaf press juice was more potent than the extract in rat hepatocytes as well as in the rat model. At a dose of $200 \mathrm{mg} /$ $\mathrm{kg}$ b.w., significant decreases of elevated serum bilirubin (SBLN) levels by the juice (105\% recovery), and of serum glutamyl pyruvate transaminase (SGPT) levels by the juice (92\% recovery) and the ethanolic extract (81\% recovery) were observed [53].

\section{Antiurolithic activity}

According to [98], B. pinnatum is used by local people in Pakistan to expel kidney stones. The authors therefore assessed the antiurolithic activity of an ethanolic extract of B. pinnatum. Fresh urine from a man was mixed with different concentrations of the extract before sodium oxalate solution was added to induce crystallization. A concentration-dependent increase of the number of crystals was observed. However, the size and the number of calcium oxalate monohydrate (COM) crystals, which are injurious to epithelial cells, were significantly reduced, and their formation was totally inhibited at the highest concentration $(100 \mathrm{mg} / \mathrm{mL})$. Moreover, the formation of calcium oxalate dihydrate (COD) crystals was promoted rather than COM, which is beneficial since COD crystals are less urolithic than COM [98]. The antiurolithic effect of an aqueous leaf extract of B. pinnatum has also been studied in rats. Kidney stones were induced by ethylene glycol. The extract administered intraperitoneally at doses of 50 and $100 \mathrm{mg} / \mathrm{kg}$ b.w. significantly reduced the urine oxalate level, improved creatinine and blood urea levels, and reduced calcium oxalate deposition in the kidneys [99].

\section{Antidiabetic activity}

Significant hypoglycemic effects were reported for oral treatment with an aqueous leaf extract of B. pinnatum (25-800 mg/kg b. w.) in normoglycemic and streptozotocin-induced diabetic Wistar rats [94].

\section{Antihypertensive activity}

An aqueous leaf extract of $B$. pinnatum was reported to reduce salt-induced hypertension in rats. Doses of 25,50 , and $100 \mathrm{mg} /$ $\mathrm{kg}$ b.w./day p.o. significantly prevented the increase of systolic and diastolic arterial pressures. On the other hand, no significant change was observed in the heart rate [100].

\section{Wound healing activity}

Topical application of an ethanolic leaf extract of B. pinnatum $(100 \mathrm{mg} / \mathrm{kg}$ b.w.) accelerated wound healing in Sprague Dawley rats. On day 11 after excision, the wound areas were reduced by $86.3 \%$, and only by $68.0 \%$ in the control group. A significant increase in wound contractions and a decrease in edema at the wound site were also observed [101].

\section{Tolerability Studies}

$\nabla$

A retrospective and two randomized prospective clinical studies confirmed good tolerability of B. pinnatum (For details, see Table 4S, Supporting Information). In tocolysis, administration of B. pinnatum $5 \%$ i.v. and $50 \%$ p.o. resulted in less side effects than under treatment with betamimetics. Specifically, the occur- rence of palpitations and dyspnea were significantly lower due to a lacking effect on $\beta_{1}$-adrenoceptors [68]. In addition, the treatment of 14 pregnant women (Bryophyllum group) with B. pinnatum $50 \%$ chewable tablets showed no side effects that were attributable to the medication [69]. Another study revealed no significant difference in observed side effects. One woman treated with B. pinnatum $50 \%$ chewable tablets suffered from diarrhea and dysentery, possibly due to lactose intolerance, and a second woman developed exanthema of the face and upper thorax [74]. In a longitudinal, prospective, randomized, controlled animal study, the effect of the mother tincture (MT), 30\% of B. pinnatum, in pregnant Wistar rats was investigated. From day 0 of gestation, 60 rats were treated with the B. pinnatum MT or pure vehicle. Two control groups, $\mathrm{C} 1$ and $\mathrm{C} 2$, received an equivalent to the usual daily dose and $25 \times$ the maximum daily dose of vehicle, respectively. Groups B1, B2, B3, and B4 received every day 1, 25, 50, and $100 \times$ the maximum daily dose of MT, respectively. After 20 days of treatment, weight gain (excluding fetal and placental weight) was higher in group B4 than in groups B1, C2, and B2. However, the perinea in group $\mathrm{C} 1$ were heavier than those in group B2. No maternal or fetal deaths, no differences in implantations and resorptions, and no differences in the number and weight of the fetuses and placentas were observed. External fetal abnormalities were not observed in groups B1-B4 [102].

\section{Toxicity Studies}

$\nabla$

B. pinnatum is well tolerated in patients. However, toxicity of Bryophyllum species has been reported to be related to bufadienolides. The cardiotoxic activity of bersaldegenin-1,3,5-orthoacetate (3) was investigated in vitro using isolated rabbit and guinea pig hearts. A strong positive inotropic effect was shown $[20,103]$. Toxicity to cattle has been documented in earlier studies. A study was conducted including two calves that were treated with the flower heads of B. pinnatum. Clinical parameters were examined after administration of $20 \mathrm{~g} / \mathrm{kg}$ b.w. by stomach tube. Five hours after dosing, the animals became depressed and suffered from rumen stasis and anorexia. The first calf died after $9 \mathrm{~h}$ due to dyspnea and tachycardia. The second calf had diarrhea until it died after $15.5 \mathrm{~h}$. This study demonstrated a correlation between bufadienolides and the toxic effect in cattle [15].

An acute toxicity study was performed with a total of 25 rats (or mice, see below), which were given either a $B$. pinnatum methanolic extract or distilled water as a single dose. Mortality was observed after $24 \mathrm{~h}$. A dose of $25 \mathrm{mg} / \mathrm{kg}$ caused neither death nor side effects, but the treatment with $200 \mathrm{mg} / \mathrm{kg}$ was lethal for $100 \%$ of the animals [96]. Unfortunately, information provided in the publication on the route of administration route (oral or intraperitoneal) and the animal species (rats or mice) is contradictory. A similar study was performed including Swiss albino mice. Intraperitoneal administration in mice of aqueous and methanolic extracts showed $\mathrm{LD}_{50}$ values of 957 and $1159 \mathrm{mg} / \mathrm{kg}$, respectively. Oral doses up to $3 \mathrm{~g} / \mathrm{kg}$ b. w. in mice and rats led to no signs of toxicity [104]. In mice, an intraperitoneally administered methanolic fraction led to no deaths up to $2500 \mathrm{mg} / \mathrm{kg}$ b.w. in mice, but their behavior changed with concentrations $>100 \mathrm{mg} / \mathrm{kg}$ b.w. [80] (See also Table 5 S, Supporting Information). 


\section{Conclusion}

\section{$\nabla$}

The introduction of B. pinnatum as an AM was based on concepts of anthroposophy, and not on scientific investigations. Meanwhile, several clinical studies support the use of the plant as a tocolytic. Recent pharmacological investigations confirmed effects on myometrial contraction, and also provided first insights into the mode of action, which appears to involve the oxytocin pathway. In addition, another "hyperactivity disease", the OAB syndrome, may represent a new therapeutic indication for $B$. pinnatum preparations. As to sleep disorders, observational studies showed a positive effect on restlessness in pregnant women and cancer patients. However, larger controlled studies are needed to confirm these preliminary data. Even if the tocolytic activity and inhibition of detrusor contractibility could be linked to a flavonoid-containing fraction, the phytochemicals responsible for the pharmacological properties and clinical effects of $B$. pinnatum are not yet entirely clear. In particular, the exact contribution of bufadienolides and flavonoids, the two characteristic groups of secondary metabolites, in the different effects remains to be established. In all clinical studies, B. pinnatum was well tolerated, and no serious side effects were observed. From a drug safety perspective, however, the quantity of bufadienolides in Bryophyllum preparations should be controlled, since some of these compounds have shown toxicity in animals. Taken together, current data confirm the potential of $B$. pinnatum for the treatment of "hyperactivity" disorders. Further studies are needed to fully understand the modes of action and to identify the active constituents. This will further consolidate the rational clinical use of B. pinnatum.

\section{Supporting information}

The full list of botanical synonyms for B. pinnatum, and detailed information regarding the settings and outcomes of the pharmacological, clinical, toxicological, and tolerability studies are provided as Supporting Information.

\section{Acknowledgements}

$\nabla$

All members of the Bryophyllum Study Group are gratefully acknowledged for their contribution to the investigation of $B$. pinnatum. The Bryophyllum Study Group includes, besides the authors, Dr. Cornelia Betschart (University Hospital Zurich), Prof. Rudolf Brenneisen (University of Bern, Switzerland), and Dr. Mónica Mennet-von Eiff and Dr. Martin Schnelle (Weleda AG, Arlesheim, Switzerland). Thanks are also due to Dr. med. Siegward-M. Elsas (Clinic Arlesheim AG, Arlesheim, Switzerland) for valuable information regarding the use of $B$. delagoense. Julia Gerber (Division of Pharmaceutical Biology, University of Basel) performed part of the literature search on bufadienolides.

\section{Conflict of Interest}

$\nabla$

Two members of the Bryophyllum Study Group, M. Mennet and M. Schnelle, are employees of Weleda AG.

\footnotetext{
References

1 Pattewar SV. Kalanchoe pinnata: phytochemical and pharmacological profile. Int J Pharm Sci Res 2012; 3: 993-1000
}

2 Kamboj A, Saluja AK. Bryophyllum pinnatum (Lam.) Kurz.: phytochemical and pharmacological profile: a review. Pharmacogn Rev 2009; 3: 364-374

3 Quazi Majaz A, Tatiya AU, Khurshid M, Nazim S, Siraj S. The miracle plant (Kalanchoe pinnata): a phytochemical and pharmacological review. Int J Res Ayurveda Pharm 2011; 2: 1478-1482

4 Milad R, El-Ahmady S, Singab AN. Genus Kalanchoe (Crassulaceae): a review of its ethnomedicinal, botanical, chemical and pharmacological properties. Eur J Med Plants 2014; 4: 86-104

5 Homöopathisches Arzneibuch 2014. Govi Verlag - Pharmazeutischer Verlag; 2014

6 Descoings B. Le genre Kalanchoe (Crassulaceae) structure et définition. J Bot Soc France 2006; 33: 3-28

7 Descoings B. Le genre Kalanchoe (Crassulaceae) structure et définition. International Crassulaceae Network. Available at http://www. crassulaceae.ch/de/artikel?akID=68\&aaID=1\&ailD=L\&aID=4779. Accessed February 16, 2016

8 Gehrig H, Gaussmann O, Marx H, Schwarzott D, Kluge M. Molecular phylogeny of the genus Kalanchoe (Crassulaceae) inferred from nucleotide sequences of the ITS- 1 and ITS-2 regions. Plant Sci 2001; 160: 827-835

9 The Plant List. Available at http://www.theplantlist.org. Accessed February 29, 2016

10 McKenzie RA, Dunster PJ. Hearts and flowers: Bryophyllum poisoning of cattle. Aust Vet J 1986; 63: 222-227

11 Capon RJ, MacLeod JK, Oelrichs PB. Structure elucidation of a new bufadienolide toxin from the flowers of Bryophyllum tubiflorum Harv. (Crassulacea). J Chem Research (S) 1985; 11: 333

12 Capon RJ, MacLeod JK, Oelrichs PB. Bryotoxins B and C, toxic bufadienolide orthoacetates from the flowers of Bryophyllum tubiflorum (Crassulaceae). Aust J Chem 1986; 39: 1711-1715

13 Fürer $K$, Raith $M$, Brenneisen $R$, Mennet $M$, Simões-Wüst AP, von Mandach $U$, Hamburger $M$, Potterat $O$. Two new flavonol glycosides and a metabolite profile of Bryophyllum pinnatum, a phytotherapeutic used in obstetrics and gynaecology. Planta Med 2013; 79: 1565-1571

14 Huang HC, Lin MK, Yang HL, Hseu YC, Liaw CC, Tseng YH, Tsuzuki M, Kuо YH. Cardenolides and bufadienolide glycosides from Kalanchoe tubiflora and evaluation of cytotoxicity. Planta Med 2013; 79: 1362-1369

15 McKenzie RA, Franke FP, Dunster PJ. The toxicity to cattle and bufadienolide content of six Bryophyllum species. Aust Vet J 1987; 64: 298301

16 Supratman U, Fujita T, Akiyama $K$, Hayashi $H$. New insecticidal bufadienolide, bryophyllin C, from Kalanchoe pinnata. Biosci Biotechnol Biochem 2000; 64: 1310-1312

17 Supratman U, Fujita T, Akiyama K, Hayashi H. Insecticidal compounds from Kalanchoe daigremontiana x tubiflora. Phytochemistry 2001; 58: 311-314

18 Supratman U, Fujita T, Akiyama K, Hayashi H, Murakami A, Sakai $H$, Koshimizu K, Ohigashi H. Anti-tumor promoting activity of bufadienolides from Kalanchoe pinnata and K. daigremontiana x tubiflora. Biosci Biotechnol Biochem 2001; 65: 947-949

19 Wagner H, Fischer M, Lotter H. Isolation and structure determination of daigremontianin, a novel bufadienolide from Kalanchoe daigremontiana. Planta Med 1985; 51: 169-170

20 Wagner $H$, Lotter $H$, Fischer $M$. The toxic and sedative bufadienolides of Kalanchoe daigremontiana Hamet et Perr. Helv Chim Acta 1986; 69: 359-367

21 Yamagishi T, Haruna M, Yan XZ, Chang JJ, Lee KH. Antitumor agents, 110. Bryophyllin B, a novel potent cytotoxic bufadienolide from Bryophyllum pinnatum. J Nat Prod 1989; 52: 1071-1079

22 Yamagishi T, Yan XZ,Wu RY, McPhail DR, McPhail AT, Lee KH. Structure and stereochemistry of bryophyllin-A, a novel potent cytotoxic bufadienolide orthoacetate from Bryophyllum pinnatum. Chem Pharm Bull 1988; 36: 1615-1617

23 Wagner H, Fischer M, Lotter H. New bufadienolides from Kalanchoe daigremontiana Hamet et Perr. (Crassulaceae). Z Naturforsch B 1985; 40 B: 1226-1227

24 Oufir M, Seiler C, Gerodetti M, Gerber J, Fürer K, Mennet-von Eiff $M$, Elsas SM, Brenneisen $R$, von Mandach U, Hamburger M, Potterat $O$. Quantification of bufadienolides in Bryophyllum pinnatum leaves and manufactured products by UHPLC-ESIMS/MS. Planta Med 2015; 81: 1190-1197

25 Gaind KN, Gupta RL. Phenolic components from the leaves of Kalanchoe pinnata. Planta Med 1973; 23: 149-153 
26 Ye YY, Yang YJ, Xia MY, Liu DC, Dai YH, Zheng L, Wang D. [Chemical constituents in herbs of Bryophyllum pinnatum]. Zhongcaoyao 2013; 44: 2642-2646

27 Muzitano MF, Tinoco LW, Guette C, Kaiser CR, Rossi-Bergmann B, Costa SS. The antileishmanial activity assessment of unusual flavonoids from Kalanchoe pinnata. Phytochemistry 2006; 67: 2071-2077

28 Tatsimo SJ, Tamokou Jde D, Havyarimana L, Csupor D, Forgo P, Hohmann J, Kuiate JR, Tane P. Antimicrobial and antioxidant activity of kaempferol rhamnoside derivatives from Bryophyllum pinnatum. BMC Res Notes 2012; 5: 158

29 Gaind KN, Gupta RL. Flavonoid glycosides from Kalanchoe pinnata. Planta Med 1971; 20: 368-373

30 Chibli LA, Rodrigues KC, Gasparetto CM, Pinto NC, Fabri RL, Scio E, Alves MS, Del-Vechio-Vieira G, Sousa OV. Anti-inflammatory effects of Bryophyllum pinnatum (Lam.) Oken ethanol extract in acute and chronic cutaneous inflammation. J Ethnopharmacol 2014; 154: 330338

31 Darmawan A, Megawati, Fajriah S. 3',4'-Dimethoxy quercetin, a flavonol compound isolated from Kalanchoe pinnata.J Appl Pharm Sci 2013; 3: $88-90$

32 Nascimento LB, Leal-Costa MV, Menezes EA, Lopes VR, Muzitano MF, Costa SS, Tavares ES. Ultraviolet-B radiation effects on phenolic profile and flavonoid content of Kalanchoe pinnata. J Photochem Photobiol B 2015; 148: 73-81

33 Coutinho MAS, Muzitano MF, Cruz EA, Bergonzi MC, Kaiser CR, Tinoco LW, Bilia AR, Vincieri FF, Rossi-Bergmann B, Costa SS. Flowers from Kalanchoe pinnata are a rich source of T cell-suppressive flavonoids. Nat Prod Commun 2012; 7: 175-178

34 Muzitano MF, Cruz EA, de Almeida AP, Da Silva SA, Kaiser CR, Guette C, Rossi-Bergmann B, Costa SS. Quercitrin: an antileishmanial flavonoid glycoside from Kalanchoe pinnata. Planta Med 2006; 72: 81-83

35 Sharker SM, Hossain MK, Haque MR, Cowdhury AA, Kaisar V, Hasan V, Rashid MA. Chemical and biological studies of Kalanchoe pinnata (Lam.) growing in Bangladesh. Asian Pac J Trop Biomed 2012; 2: S1317-S1322

36 Ogungbamila FO, Onavunmi GO, Adeosun O. A new acylated flavan-3-ol from Bryophyllum pinnatum. Nat Prod Lett 1997; 10: 201-203

37 Okwu DE, Nnamdi FU. Two novel flavonoids from Bryophyllum pinnatum and their antimicrobial activity. J Chem Pharm Res 2011; 3: 1-10

38 Huang HC, Huang GJ, Liaw CC, Yang CS, Yang CP, Kuo CL, Tseng YH, Wang SY, Chang WT, Kuo YH. A new megastigmane from Kalanchoe tubiflora (Harvey) Hamet. Phytochem Lett 2013; 6: 379-382

39 Gaind KN, Gupta RL. Alkanes, alkanols, triterpenes, and sterols of Kalanchoe pinnata. Phytochemistry 1972; 11: 1500-1502

40 Afzal M, Gupta G, Kazmi I, Rahman M, Afzal O, Alam J, Hakeem KR, Pravez M, Gupta R, Anwar F. Anti-inflammatory and analgesic potential of a novel steroidal derivative from Bryophyllum pinnatum. Fitoterapia 2012; 83: 853-858

41 Siddiqui S, Faizi S, Siddiqui BS, Sultana N. Triterpenoids and phenanthrenes from leaves of Bryophyllum pinnatum. Phytochemistry 1989; 28: 2433-2438

42 Akihisa T, Kokke WCMC, Tamura T, Matsumoto T. Sterols of Kalanchoe pinnata: first report of the isolation of both C-24 epimers of 24-alkyl- $\Delta 25$-sterols from a higher plant. Lipids 1991; 26: 660-665

43 Sharker SM, Hossain MK, Haque MR, Hamidul Kabir ANM, Hasan CM, Rashid MA. Phytochemical and pharmacological studies of Bryophyllum daigremontianum (Raym.). Am J PharmTech Res 2013; 3: 484-492

44 Jetter R, Sodhi R. Chemical composition and microstructure of waxy plant surfaces: triterpenoids and fatty acid derivatives on leaves of Kalanchoe daigremontiana. Surf Interface Anal 2011; 43: 326-330

45 Van Maarseveen C, Jetter R. Composition of the epicuticular and intracuticular wax layers on Kalanchoe daigremontiana (Hamet et Perr. De la Bathie) leaves. Phytochemistry 2009; 70: 899-906

46 Okwu DE, Nnamdi FU. A novel antimicrobial phenanthrene alkaloid from Bryopyllum pinnatum. E-J Chem 2011; 8: 1456-1461

47 Almeida AP, Muzitano MF, Costa SS. 1-Octen-3-O- $\alpha$-L-arabinopyranosyl-( $1 \rightarrow 6)$ - $\beta$-glucopyranoside, a minor substance from the leaves of Kalanchoe pinnata (Crassulaceae). Rev Bras Farmacogn 2006; 16: 485489

48 Nair MG, Epp MD, Burke BA. Ferulate esters of higher fatty alcohols and allelopathy in Kalanchoe daigremontiana. J Chem Ecol 1988; 14: 589603

49 Almeida AP, Da Silva SA, Souza ML, Lima LM, Rossi-Bergmann B, de Moraes VL, Costa SS. Isolation and chemical analysis of a fatty acid fraction of Kalanchoe pinnata with a potent lymphocyte suppressive activity. Planta Med 2000; 66: 134-137

50 Kruk J, Pisarski A, Szymanska R. Novel vitamin E forms in leaves of Kalanchoe daigremontiana and Phaseolus coccineus. J Plant Physiol 2011; 168: 2021-2027

51 Lans CA. Ethnomedicines used in Trinidad and Tobago for urinary problems and diabetes mellitus. J Ethnobiol Ethnomed 2006; 2: 45

52 Salami EO, Ozolua RI, Okpo SO, Eze GI, Uwaya DO. Studies on the antiasthmatic and antitussive properties of aqueous leaf extract of Bryophyllum pinnatum in rodent species. Asian Pac J Trop Med 2013; 6: 421-425

53 Yadav NP, Dixit VK. Hepatoprotective activity of leaves of Kalanchoe pinnata Pers. J Ethnopharmacol 2003; 86: 197-202

54 Pal S, Nag Chaudhuri AK. Studies on the anti-ulcer activity of a Bryophyllum pinnatum leaf extract in experimental animals. J Ethnopharmacol 1991; 33: 97-102

55 Kirtikar KR, Basu BD. Indian medicinal plants, Vol. 2. Dehradrun: Bishen Singh Mahendra Pal Singh; 1975: 999

56 Willcox ML, Bodeker G. Traditional herbal medicines for malaria. Brit Med J 2004; 329: 1156-1159

57 Rist L, Seitz-Gwehenberger B, Kukck A, von Mandach U. Zum Verständnis von Bryophyllum als Planze und Medikament. Der Merkurstab 2006; 4: 298-307

58 Leuenberger M. Bryophyllum in der Frauenheilkunde. Weleda Ärzteforum 2006; 16: 1-8

59 Daems W, Kaufmann H, Titze O. Kurzgefasste Bryophylum-Chronolgie. Weleda Korrespondenzblätter für Ärzte 1982; 105: 5-11

60 Von Mandach U, Simões-Wüst AP, Kuck A, Betschart C. Bryophyllum pinnatum in der Geburtshilfe und Gynäkologie. Wirksamkeit und Verträglichkeit. Info@gynäkologie 2011; 3: 16-19

61 Hassauer W, Schreiber K, von der Decken D. Bryophyllum - Ein neuer Weg in der tokolytischen Therapie. Erfahrungsheilkunde 1985; 34: 683-687

62 Simões-Wüst AP, Jeschke $E$, Mennet $M$, Schnelle $M$, Matthes $H$, von Mandach $U$. Prescribing pattern of Bryophyllum preparations among a network of anthroposophic physicians. Forsch Komplementmed 2012; 19: 293-301

63 Gesellschaft Anthroposophischer Ärzte in Deutschland und der Medizinischen Sektion der Freien Hochschule für Geisteswissenschaft, Dornach, Schweiz. Vademecum Anthroposophische Arzneimittel, 3rd edition. Berlin: Der Merkurstab; 2013: 178-183

64 Gesellschaft Anthroposophischer Ärzte in Deutschland im Auftrag der Medizinischen Sektion am Goetheanum Dornach, Schweiz. Anthroposophische Arzneimittel: Aufbereitungsmonographien der Kommission C. Filderstadt: Gesellschaft Anthroposophischer Ärzte in Deutschland; 1999: 272-277

65 FürerK,Simões-Wuest AP, WinklerA,AmslerN,Schnelle M, von MandachU. Die Anwendung von Bryophyllum pinnatum-Präparaten in der Geburtshilfe und Gynäkologie - eine multizentrische prospektive Beobachtungsstudie. Forsch Komplementmed 2015; 22: 231-236

66 Daub E. Vorzeitige Wehentätigkeit: Ihre Behandlung mit pflanzlichen Substanzen - eine klinische Studie. Stuttgart: Urachhaus; 1989

67 Vilaghy I. Senkung der Frühgeburtenrate mit Phytotherapie-Ergebnisse aus der Praxis. Ther Umsch 2002; 59: 696-701

68 Plangger N, Rist L, Zimmermann R, von Mandach U. Intravenous tocolysis with Bryophyllum pinnatum is better tolerated than beta-agonist application. Eur J Obstet Gynecol Reprod Biol 2006; 124: 168-172

69 Wächter R. Klinische Wirksamkeit, Pharmakologie und Analytik von Bryophyllum pinnatum [Dissertation]. Basel: University of Basel; 2010

70 Gwehenberger B, Rist L, Huch R, von Mandach U. Effect of Bryophyllum pinnatum versus fenoterol on uterine contractility. Eur J Obstet Gynecol Reprod Biol 2004; 113: 164-171

71 Wächter $R$, Brenneisen $R$, Hamburger $M$, Mennet $M$, Schnelle $M$, Worel AM, Simões-Wüst AP, von Mandach $U$. Leaf press juice from Bryophyllum pinnatum (Lamarck) Oken induces myometrial relaxation. Phytomedicine 2011; 19: 74-82

72 Simões-Wüst AP, Graos M, Duarte CB, Brenneisen R, Hamburger $M$, Mennet $M$, Ramos $M H$, Schnelle $M$, Wächter $R$, Worel $A M$, von Mandach $U$. Juice of Bryophyllum pinnatum (Lam.) inhibits oxytocininduced increase of the intracellular calcium concentration in human myometrial cells. Phytomedicine 2010; 17: 980-986

73 Haylen BT, de Ridder D, Freeman RM, Swift SE, Berghmans B, Lee J, Monga A, Petri E, Rizk DE, Sand PK, Schaer GN. An International Urogynecological Association (IUGA)/International Continence Society 
(ICS) joint report on the terminology for female pelvic floor dysfunction. Neurourol Urodyn 2010; 29: 4-20

74 Betschart C, von Mandach U, Seifert B, Scheiner D, Perucchini D, Fink D, Geissbühler V. Randomized, double-blind placebo-controlled trial with Bryophyllum pinnatum versus placebo for the treatment of overactive bladder in postmenopausal women. Phytomedicine 2013; 20: 351 358

75 Schuler V, Suter K, Fürer K, Eberli D, Horst M, Betschart C, Brenneisen R, Hamburger M, Mennet M, Schnelle M, Simões-Wüst AP, von Mandach $U$. Bryophyllum pinnatum inhibits detrusor contractility in porcine bladder strips - a pharmacological study towards a new treatment option of overactive bladder. Phytomedicine 2012; 19: 947-951

76 Fürer K, Eberli D, Betschart C, Brenneisen R, De Mieri M, Hamburger $M$, Mennet-von Eiff $M$, Potterat $O$, Schnelle $M$, Simões-Wüst AP, von Mandach $U$. Inhibition of porcine detrusor contractility by the flavonoid fraction of Bryophyllum pinnatum - a potential phytotherapeutic drug for the treatment of the overactive bladder syndrome. Phytomedicine 2015; 22: 158-164

77 Lambrigger-Steiner C, Simões-Wüst AP, Kuck A, Fürer K, Hamburger M, von Mandach $U$. Sleep quality in pregnancy during treatment with Bryophyllum pinnatum: an observational study. Phytomedicine 2014; 21: 753-757

78 Simões-Wüst AP, Hassani TA, Muller-Hubenthal B, Pittl S, Kuck A Meden H, Eberhard J, Decker M, Fürer K, von Mandach U. Sleep quality improves during treatment with Bryophyllum pinnatum: an observational study on cancer patients. Integr Cancer Ther 2015; 14: 452-459

79 Yemitan OK, Salahdeen HM. Neurosedative and muscle relaxant activities of aqueous extract of Bryophyllum pinnatum. Fitoterapia 2005; 76: 187-193

80 Pal S, Sen T, Chaudhuri AK. Neuropsychopharmacological profile of the methanolic fraction of Bryophyllum pinnatum leaf extract. J Pharm Pharmacol 1999; 51: 313-318

81 Ofokansi KC, Esimone CO, Anele R. Evaluation of the in vitro combined antibacterial effect of the leaf extracts of Bryophyllum pinnatum (Fam. Crassulaceae) and Ocimum gratissimum (Fam. Labiatae). Plant Product Res 2005; 9: 23-27

82 Akinpelu DA. Antimicrobial activity of Bryophyllum pinnatum leaves. Fitoterapia 2000; 71: 193-194

83 Torres-Santos EC, Da Silva SAG, Costa SS, Santos APPT, Almeida AP, RossiBergmann $B$. Toxicological analysis and effectiveness of oral Kalanchoe pinnata on a human case of cutaneous leishmaniasis. Phytother Res 2003; 17: 801-803

84 Da Silva SA, Costa SS, Mendonca SC, Silva EM, Moraes VL, RossiBergmann B. Therapeutic effect of oral Kalanchoe pinnata leaf extract in murine leishmaniasis. Acta Trop 1995; 60: 201-210

85 Da Silva SA, Costa SS, Rossi-Bergmann B. The anti-leishmanial effect of Kalanchoe is mediated by nitric oxide intermediates. Parasitology 1999; 118: 575-582

86 Muzitano MF, Falcao CA, Cruz EA, Bergonzi MC, Bilia AR, Vincieri FF, Rossi-Bergmann B, Costa SS. Oral metabolism and efficacy of Kalanchoe pinnata flavonoids in a murine model of cutaneous leishmaniasis. Planta Med 2009; 75: 307-311

87 Mahata S, Maru S, Shukla S, Pandey A, Mugesh G, Das BC, Bharti AC. Anticancer property of Bryophyllum pinnata (Lam.) Oken. leaf on human cervical cancer cells. BMC Complement Altern Med 2012; 12: 15

88 Hsieh YJ, Yang MY, Leu YL, Chen C, Wan CF, Chang MY, Chang CJ. Kalanchoe tubiflora extract inhibits cell proliferation by affecting the mitotic apparatus. BMC Complement Altern Med 2012; 12: 149
89 Hsieh YJ, Huang HS, Leu YL, Peng KC, Chang CJ, Chang MY. Anticancer activity of Kalanchoe tubiflora extract against human lung cancer cells in vitro and in vivo. Environ Toxicol advance online publication 15 July 2015; DOI: $10.1002 /$ tox.22170

90 Nascimento LB, Leal-Costa MV, Coutinho MA, Moreira Ndos S, Lage CL, Barbi Ndos S, Costa SS, Tavares ES. Increased antioxidant activity and changes in phenolic profile of Kalanchoe pinnata (Lamarck) Persoon (Crassulaceae) specimens grown under supplemental blue light. Photochem Photobiol 2013; 89: 391-399

91 Nassis CZ, Haebisch EM, Giesbrecht AM. Antihistamine activity of Bryophyllum calycinum. Braz J Med Biol Res 1992; 25: 929-936

92 Cruz EA, Da Silva SA, Muzitano MF, Silva PM, Costa SS, RossiBergmann $B$. Immunomodulatory pretreatment with Kalanchoe pinnata extract and its quercitrin flavonoid effectively protects mice against fatal anaphylactic shock. Int Immunopharmacol 2008; 8: 1616-1621

93 Cruz EA, Reuter S, Martin H, Dehzad N, Muzitano MF, Costa SS, RossiBergmann B, Buhl R, Stassen M, Taube C. Kalanchoe pinnata inhibits mast cell activation and prevents allergic airway disease. Phytomedicine 2012; 19: 115-121

94 Ojewole JA. Antinociceptive, anti-inflammatory and antidiabetic effects of Bryophyllum pinnatum (Crassulaceae) leaf aqueous extract. J Ethnopharmacol 2005; 99: 13-19

95 Ferreira RT, Coutinho MAS, Malvar DC, Costa EA, Florentino IF, Costa SS, Vanderlinde FA. Mechanisms underlying the antinociceptive, antiedematogenic and anti-inflammatory activity of the main flavonoid from Kalanchoe pinnata. Evid Based Complement Alternat Med 2014; 2014: 429256

96 Adesanwo JK, Raji Y, Olaleye SB, Onasanwo SA, Fadare OO, Ige OO, Odusanya OO. Antiulcer activity of methanolic extract of Bryophyllum pinnatum in rats. J Biol Sci 2007; 7: 409-412

97 Igwe SA, Akunyili DN. Analgesic effects of aqueous extracts of the leaves of Bryophyllum pinnatum. Pharm Biol 2005; 43: 658-661

98 Yasir F, Waqar MA. Effect of indigenous plant extracts on calcium oxalate crystallization having a role in urolithiasis. Urol Res 2011; 39: $345-350$

99 Shukla AB, Mandavia DR, Barvaliya MJ, Baxi SN, Tripathi CR. Evaluation of anti-urolithiatic effect of aqueous extract of Bryophyllum pinnatum (Lam.) leaves using ethylene glycol-induced renal calculi. Avicenna J Phytomed 2014; 4: 151-159

100 Bopda OSM, Longo F, Bella TN, Edzah PMO, Taïwe GS, Bilanda DC, Tom ENL, Kamtchouing P, Dimo T. Antihypertensive activities of the aqueous extract of Kalanchoe pinnata (Crassulaceae) in high saltloaded rats. J Ethnopharmacol 2014; 153: 400-407

101 Nayak BS, Marshall JR, Isitor G. Wound healing potential of ethanolic extract of Kalanchoe pinnata Lam. leaf - a preliminary study. Indian J Exp Biol 2010; 48: 572-576

102 Hosomi JK, Ghelman R, Quintino MP, de Souza E, Nakamura MU, Moron AF. Effects of chronic Bryophyllum pinnatum administration on Wistar rat pregnancy. Forsch Komplementmed 2014; 21: 184-189

103 Scholtysik G, Wagner H, Fischer M, Ruegg U. Cardiac glycoside-like effects of a bufadienolide extracted from Kalanchoe daigremontiana. In: Erdmann E, Greeff K, Skou JC, editors. Cardiac glycosides 17851985. Berlin, Heidelberg: Springer; 1986: 171-179

104 Devbhuti D, Gupta JK, Devbhuti P, Bose A. Phytochemical and acute toxicity study on Bryophyllum calycinum Salisb. Acta Pol Pharm 2008; 65 : 501-504 